\title{
Rural Children Increasingly Rely on Medicaid and State Child Health Insurance Programs for Medical Care
}

B Y W ILLIA M P. O'HARE

\section{Summary}

THE INCREASING NUMBER of American children with health insurance coverage over the past ten years has been driven by increased coverage for children in low-income families, which is the result of expanded coverage by Medicaid and SCHIP. There is widespread agreement that the expansion of Medicaid and introduction of SCHIP have worked. The increased effectiveness of these public-sector health insurance programs more than offset the decrease in coverage through the private sector.

Despite a recent flurry of reports on health insurance coverage for children, virtually none of them have examined the unique situation of rural families where one-fifth of all of our nation's poor children live. Data presented in this report show that the experience of children in small towns and rural areas often differs from the experience of their big-city counterparts. The nationwide shift to public-sector health insurance coverage for children is even more pronounced for rural America where more than one-third of all children rely on SCHIP and Medicaid for health care. Enrollment in SCHIP and Medicaid is 6 percentage points higher for rural children than for urban children. Given the deteriorating job situation in many parts of rural America, the availability of public-sector health insurance for the families of low-income workers is even more important in rural areas than in other parts of the country.

\section{Introduction to the State Child Health Insurance Program}

ONE OF THE MOST SIGNIFICANT social policy measures of the past decade was the State Child Health Insurance Program (SCHIP), passed by Congress in 1997. SCHIP, which has strong bipartisan support, helps states provide health care coverage for children in low-income families through expanding the Medicaid program, developing a new freestanding child health insurance program, or some combination of these two approaches. ${ }^{1}$ In 1997, Congress appropriated $\$ 40$ billion to be distributed to the states over 10 years to support this program, which means SCHIP is up for re-authorization this year. More than 6 million children received benefits from the SCHIP program at some point during $2004 .^{2}$

It is important to recognize that SCHIP builds on the Medicaid program. Approximately 28 million children receive health insurance under the Medicaid program compared to 6 million under SCHIP. ${ }^{3}$ Medicaid is targeted to the lowest income families, but SCHIP is designed to reach those low-income families who are earning too much to qualify for Medicaid but have jobs that do not provide health insurance and/or they make too little to be able to afford health insurance on the private market. It turns out that many children who applied for SCHIP over the past ten years were actually eligible for Medicaid. The increased health insurance coverage for children over the past ten years is due as much to increased use of Medicaid as it is to increased use of SCHIP. 


\section{Key Findings}

- In both urban and rural areas, 11 percent of all children lack health insurance which amounts to 8.3 million children nationally (the number is closer to 9 million if you include 19-year-olds, most of whom are eligible for SCHIP)

- Of the 8.3 million uninsured children about 1.3 million live in rural areas.

- 32 percent of all rural children rely on SCHIP and Medicaid compared to 26 percent of all urban children,

- In 2005, nearly 4 million children in rural areas depended on public-sector health insurance.

- Among children at all income levels, the use of Medicaid and SCHIP is 6 percentage points higher for children in rural America than those in urban America. But that is largely due to the fact that a higher percentage of rural children live in low-income families.

- In 2005, 17 percent of low-income rural children are uninsured which is nearly the same as the 18 percent rate for similar children in urban areas.

- Over half (53 percent) of low-income children in rural America rely on SCHIP and Medicaid which is nearly identical to 52 percent of low-income urban children.

- The percent of low-income rural children covered by private insurance declined by 8 percentage points between 2000 and 2005 compared to 6 percentage points for similar urban children.

Table 1. Health Insurance Coverage for Children (Under Age 18) By Metro (Urban) AND Nonmetro (RURAL) AreAS: 1995 TO 2005

\begin{tabular}{cccc}
\hline \multicolumn{4}{c}{ ALL CHILDREN } \\
\hline \multicolumn{4}{c}{ Percentage Without Health Insurance } \\
\hline Year & Metropolitan Areas (Urban) & Nonmetropolitan Area (Rural) & Total \\
\hline 1995 & 14 & 15 & 14 \\
1996 & 13 & 15 & 15 \\
1997 & 14 & 17 & 15 \\
1998 & 15 & 16 & 15 \\
1999 & 15 & 16 & 13 \\
2000 & 14 & 14 & 12 \\
2001 & 12 & 11 & 12 \\
2002 & 12 & 12 & 12 \\
2003 & 12 & 12 & 11 \\
2004 & 11 & 11 & 11 \\
2005 & 11 & 11 & 11 \\
\hline
\end{tabular}

Source: Census Bureau's March Current Population Surveys

\section{The Numbers of Uninsured Children Decline}

The SCHIP program has been widely viewed as successful because the share of children lacking health insurance has declined dramatically over the past decade. The percent of all children (under age 18) lacking health insurance has fallen from 15 percent in 1997 to 11 percent in 2005. The percentage of children lacking health insurance has declined to approximately 11 percent in both urban and rural areas over the past decade (see Table 1$){ }^{4}$

The decrease in the share of all children lacking health insurance has been driven by a steep increase in the share of poor and near poor children (those with family incomes under 200 percent of the federal poverty level) who have health insurance. The percentage of children in low-income families lacking health insurance fell from 24 percent in 1997 to 18 percent in 2005 while the share of children in more affluent families (with incomes above 200 percent of poverty) remained nearly constant. ${ }^{5}$

\section{Trends Among Low-income Children}

\section{Numbers Covered by Private Insurance on the Decline}

In 2005, 32 percent of all rural children relied on SCHIP or Medicaid for health insurance compared to 26 percent of all urban children. ${ }^{6}$ The higher poverty rate among rural children helps explain why the share of children covered by public-sector health insurance is higher in rural than urban America. In 2005, 47 percent of rural children lived in lowincome families (defined here as those with income less than 200 percent of the poverty line) compared with 38 percent of urban children. ${ }^{7}$ Because the SCHIP and Medicaid programs were designed specifically to serve children in impoverished and low-income families, it is important to examine trends in the health insurance coverage of this population. In 2005, a little over half of all children in low-income families (53 percent in rural areas and 52 percent in urban areas) were covered by SCHIP or Medicaid (see Table 2).

Both rural and urban children in low-income families have seen significant shifts during the past decade in the source of their health insurance coverage. In short, fewer children have private insurance (largely through their parent's employment) and more are insured through the public sector (largely SCHIP or Medicaid).

Table 2 shows the type of insurance coverage for rural and urban children living in low-income families each year from 1995 to 2005 (See Data and Methods for information on data collection and terminology). The overall trends in privatesector insurance coverage for children were in the same 
Table 2. Low-Income Child Insurance by Type And by Metro Status: 1995 to 2005

\begin{tabular}{|c|c|c|c|c|c|c|c|c|c|c|}
\hline \multirow[b]{3}{*}{ Year } & \multicolumn{5}{|c|}{ INSIDE METROPOLITAN AREAS (URBAN) } & \multicolumn{5}{|c|}{ OUTSIDE METROPOLITAN AREAS (RURAL) } \\
\hline & \multirow[b]{2}{*}{$\begin{array}{l}\text { Number of } \\
\text { children. } \\
\text { (in 1000s) }\end{array}$} & \multirow[b]{2}{*}{$\begin{array}{l}\text { Private-Sector } \\
\text { Insurance }\end{array}$} & \multicolumn{2}{|c|}{ Public-Sector Insurance } & \multirow[b]{2}{*}{$\begin{array}{c}\text { No } \\
\text { Insurance }\end{array}$} & \multirow[b]{2}{*}{$\begin{array}{l}\text { Number of } \\
\text { children } \\
\text { (in 1000s) }\end{array}$} & \multirow[b]{2}{*}{$\begin{array}{l}\text { Private-Sector } \\
\text { Insurance }\end{array}$} & \multicolumn{2}{|c|}{ Public-Sector Insurance } & \multirow[b]{2}{*}{ No Insurance } \\
\hline & & & $\begin{array}{l}\text { All Public } \\
\text { Sector }\end{array}$ & $\begin{array}{l}\text { SCHIP and } \\
\text { Medicaid } \\
\text { only }\end{array}$ & & & & $\begin{array}{l}\text { All Public } \\
\text { Sector }\end{array}$ & $\begin{array}{l}\text { SCHIP and } \\
\text { Medicaid } \\
\text { only }\end{array}$ & \\
\hline & & $\%$ & $\%$ & $\%$ & $\%$ & & $\%$ & $\%$ & $\%$ & $\%$ \\
\hline 1995 & 23,122 & 36 & 49 & 47 & 22 & 7,336 & 45 & 44 & 41 & 21 \\
\hline 1996 & 23,047 & 37 & 47 & 44 & 23 & 7,418 & 42 & 41 & 39 & 24 \\
\hline 1997 & 22,375 & 38 & 45 & 42 & 24 & 6,916 & 42 & 43 & 41 & 23 \\
\hline 1998 & 22,286 & 38 & 45 & 43 & 25 & 6,289 & 47 & 38 & 36 & 23 \\
\hline 1999 & 21,518 & 39 & 46 & 43 & 22 & 6,240 & 46 & 42 & 40 & 20 \\
\hline 2000 & 21,049 & 40 & 46 & 43 & 21 & 5,834 & 45 & 49 & 46 & 15 \\
\hline 2001 & 21,311 & 38 & 49 & 47 & 20 & 6,145 & 42 & 51 & 48 & 16 \\
\hline 2002 & 21,696 & 36 & 51 & 48 & 20 & 6,079 & 39 & 53 & 49 & 17 \\
\hline 2003 & 22,586 & 35 & 54 & 52 & 19 & 5,940 & 37 & 57 & 54 & 15 \\
\hline 2004 & 23,101 & 36 & 54 & 52 & 18 & 5,467 & 37 & 59 & 57 & 14 \\
\hline 2005 & 23,259 & 34 & 55 & 52 & 18 & 5,073 & 37 & 54 & 53 & 17 \\
\hline
\end{tabular}

Note: Low income are those living below $200 \%$ of the federal poverty line.

Source: Census Bureau's March CPS files from the following year

Detail may total to more than $100 \%$ because some children may be covered by more then one insurance type.

direction in rural and urban areas, but the post-2000 decline in private-sector insurance coverage was more pronounced for rural children. ${ }^{8}$

Private-sector coverage remained relatively high during the economically robust period of the late 1990s, but the coverage rates fell dramatically after 2000. Among rural children living in low-income families, there was an 8 percentage point decrease in private-sector coverage between 2000 and 2005 (45 percent to 37 percent). The decline in private-sector insurance coverage for low-income urban children was also precipitous after 2000.

This steep decline in private-sector coverage among rural children reflects the deteriorating quality of jobs in many parts of rural America during the 2000 to 2005 period. Many of the sectors in rural America offering employees relatively high rates of insurance have been in decline in recent years. ${ }^{9}$ For example, three-quarters of the children living in families whose head of household works in manufacturing are insured through parent's employer, but the number of rural workers in manufacturing has decreased precipitously since 2000. ${ }^{10}$ More and more jobs in rural America do not offer health insurance, or health insurance is offered at a price that workers cannot afford to pay. The deteriorating income for many workers in rural America is reflected in the fact that the share of rural children whose families were insured by privately purchased health insurance fell from 8 percent in 1995 to 4 percent in 2005. Among urban kids this figure stayed steady at 4 percent over this period. One analysis shows that rural workers are more likely than urban workers to be earning less than $\$ 7.25$ an hour and therefore will be affected by the new minimum wage being considered by Congress. ${ }^{11}$

\section{Numbers Using Public Health Insurance on the Rise}

From 1997 (when SCHIP was passed) to 2004, the share of low-income children in rural areas dependent on Medicaid or SCHIP increased from 41 percent to 57 percent, but then the share of rural children in low-income families covered by SCHIP and Medicaid fell to 53 percent in $2005 .{ }^{12}$ The share of low-income urban children covered by SCHIP or Medicaid increased steadily from 42 percent to 52 percent from 1997 to 2005 (see Table 2).

To summarize, the overall increase in health insurance coverage for rural children over the past decade was due to an increase in public-sector insurance that more than made up for the decrease in private-sector insurance. In 2005, 2.5 million low-income children in rural areas depended on public-sector health insurance.

\section{Many Children Who Lack Insurance Are Eligible for Public Coverage}

Despite the successes of SCHIP and Medicaid, there are still well over 8 million children under age 18 (nearly 9 million children under age 19) who lack health insurance. About one-sixth of all uninsured children (1.3 million) live in rural 
Table 3. Characteristics of Uninsured Children in RuRal and Urban America: 2005

\begin{tabular}{|c|c|c|c|c|c|c|}
\hline \multirow[t]{2}{*}{ Children Under Age 18 in Households } & \multicolumn{3}{|c|}{ Inside Metropolitan Areas (Urban) } & \multicolumn{3}{|c|}{ Outside Metropolitan Areas (Rural) } \\
\hline & $\begin{array}{l}\text { Without } \\
\text { insurance } \\
\text { (in } 1,000 \text { s) }\end{array}$ & $\begin{array}{l}\text { Percent of } \\
\text { Group } \\
\text { Uninsured }\end{array}$ & $\begin{array}{l}\text { Number as a } \\
\text { Percent of all } \\
\text { the Uninsured }\end{array}$ & $\begin{array}{l}\text { Without } \\
\text { insurance } \\
\text { (in } 1,000 \text { s) }\end{array}$ & $\begin{array}{c}\text { Percent of } \\
\text { Group } \\
\text { Uninsured }\end{array}$ & $\begin{array}{l}\text { Number as a } \\
\text { Percent of } \\
\text { Uninsured }\end{array}$ \\
\hline All children & 6,967 & 11 & 100 & 1,270 & 12 & 100 \\
\hline under age 5 & 1,859 & 11 & 27 & 322 & 12 & 25 \\
\hline age 5 to 11 & 2,360 & 10 & 34 & 453 & 11 & 36 \\
\hline age 12 to 17 & 2,748 & 13 & 39 & 495 & 12 & 39 \\
\hline \multicolumn{7}{|l|}{ Householder works 35 or more hr/week and } \\
\hline 50 or more weeks a year & 3,687 & 10 & 53 & 686 & 10 & 54 \\
\hline Any adult (18 or more) in household & & & & & & \\
\hline works 35 or more hours/week and 50 or more weeks a year & 5,363 & 10 & 77 & 997 & 12 & 79 \\
\hline Family income less than poverty & 2,199 & 20 & 32 & 406 & 18 & 32 \\
\hline Family income $100-199 \%$ of poverty & 2,199 & 17 & 32 & 489 & 17 & 38 \\
\hline Family income $200 \%$ or more of poverty & 2,569 & 7 & 37 & 375 & 6 & 30 \\
\hline In married-couple family & 3,900 & 9 & 56 & 721 & 10 & 57 \\
\hline In single-parent family & 3,067 & 16 & 44 & 550 & 15 & 43 \\
\hline Non-Hispanic white & 2,316 & 7 & 33 & 750 & 9 & 59 \\
\hline non-Hispanc Black & 1,155 & 12 & 17 & 172 & 14 & 14 \\
\hline Hispanic & 2,987 & 22 & 43 & 223 & 23 & 18 \\
\hline Owns home & 3,595 & 9 & 52 & 824 & 10 & 65 \\
\hline Rents home & 3,372 & 16 & 48 & 447 & 15 & 35 \\
\hline
\end{tabular}

Source: March 2006 CPS

areas (see Table 3). There is also growing concern because there was a statistically significant increase in the percent of children without health insurance between 2004 and 2005 according to the most recent data available. ${ }^{13}$ Note that all of the national increase between 2004 and 2005 was due to changes among children living in rural America.

Furthermore, these figures reflect only those children who lacked insurance for the entire year. One study found that more than 37 percent of all children (more than 20 million) lacked health insurance for a portion of the year. ${ }^{14}$ Many children cycle on and off of insurance as their parent's work status changes. The availability of SCHIP and Medicaid is particularly important for children whose parents are seasonal or cyclical workers, and those types of jobs are more prevalent in rural areas. Without public-sector health insurance, those who move in and out of the labor force, or from job to job, often lack continuity in coverage for their family. There is also some evidence that many people with insurance are under-insured. ${ }^{15}$ The point here is that the numbers used in this report reflect children who lack any health insurance for an entire year, and probably underestimate the true magnitude of the problem .

Of the 8.3 million children lacking health insurance, more than two-thirds live in families whose low incomes qualify them for SCHIP or Medicaid. (see Table 3). In rural areas, 70 percent (900,000 out of 1.3 million) of children who lack health insurance live in low-income households compared to 63 percent (4.4 million out of 7 million) of urban children.

There are many reasons why children who appear to be eligible for government health insurance are not insured. Many families don't realize their children are eligible for government-sponsored health insurance. This is particularly true for low-income working families, which are home to so many of our uninsured children. In rural areas, lowincome families are often required to travel long distances to apply for SCHIP or Medicaid, which discourages participation. Language or cultural barriers can also discourage participation.

\section{Majority of Uninsured Are in Working Families}

More than one-half (54 percent) of uninsured children in rural areas live in families where the head of the household works full-time (35 or more hours per week) year-round (50 or more weeks a year) (see Table 3 ). The figure is virtually the same among children in urban areas. Many more children live with parents who work in part-time or temporary jobs, which typically do not provide health insurance. More than three-quarters of uninsured children live in a household where some adult works at a full-time job.

Many of the characteristics of children who lack health insurance mirror those of disadvantaged children in 


\section{Significant Differences Exist Among States and Counties}

The broad national patterns and trends identified in the previous section mask significant differences among states. Table 4 shows the share of rural children in each state who lack health insurance. The states with the lowest rates of uninsured children in rural areas are Vermont with 5 percent uninsured, followed by Kansas, Michigan, Nebraska, and New Hampshire, each of which reported 6 percent of its children were uninsured. The states with the highest percentage of uninsured rural children are Colorado (19 percent), and New Mexico and Texas (both 18 percent).

Regionally, the states with the highest rates of uninsured children are located in the West and Southwest, while those with relatively low rates are located in the Northeast and Midwest. These are the same geographic patterns seen in overall child well-being, which means the lack of health insurance often compounds other problems such as poverty and poor health. ${ }^{16}$
Although the SCHIP and Medicaid programs are largely federal programs, they obviously differ in their impact across the states. The large differences among the states in terms of uninsured children highlight the important role state governments play in ensuring access to health care for vulnerable children. To some extent, the state differences also reflect state demographics.

Examining differences by county sheds additional light on rural uninsured children. ${ }^{17}$ Table 5 shows that of the 50 counties with the highest rate of uninsured children (all above 26 percent), 44 are outside metropolitan areas. Moreover, many of these nonmetropolitan counties with high rates of uninsured children are located in the most remote and isolated parts of the country. Three-fourths of the counties with highest rates of uninsured children are in the South or Southwest, with 33 of the 50 counties located in Texas.

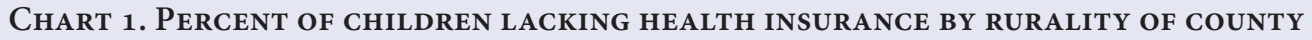

The rural/urban dichotomy used in most of this analysis does not fully capture the extent to which the most rural counties have the highest rates of uninsured children. This chart, based on Census Bureau data from 2000, shows a clear linear relationship between a counties' rurality and the percent of children lacking health insurance. The most urban counties have the lowest percentage of children without health insurance (9.9\%) and the most rural counties have the highest percentage of children lacking health insurance (15.2\%). The rate of children lacking health insurance in the most rural counties is 50 percent higher than the rate for the most urban set of counties.

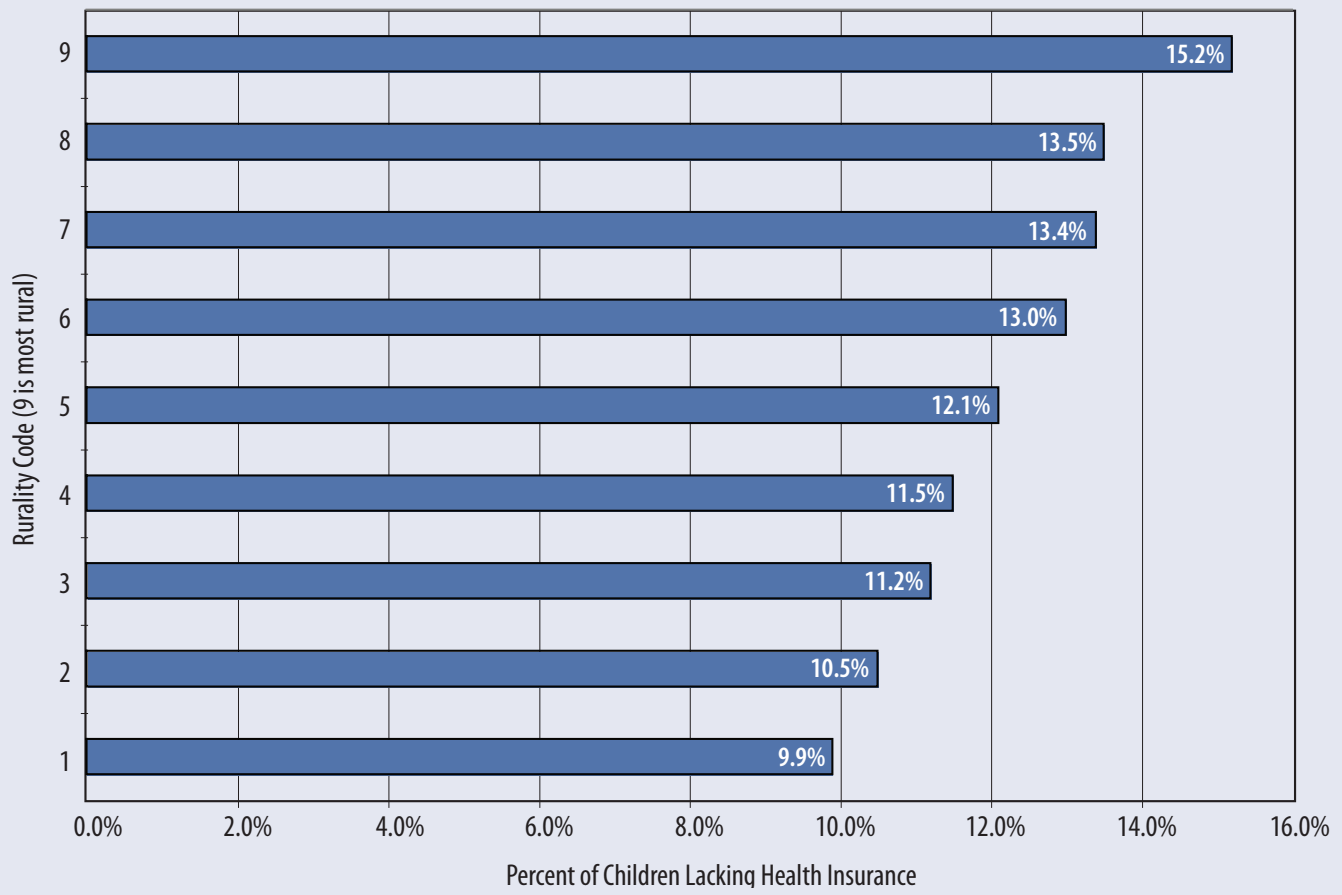


Table 4. States Ranked by Child Health Insurance Coverage For Rural (NoNmetropolitan) Areas: $2004^{*}$

\begin{tabular}{|c|c|c|c|}
\hline & & $\begin{array}{l}\text { Percentage with } \\
\text { No Health Insurance }\end{array}$ & $\begin{array}{l}\text { Number with } \\
\text { No Health Insurance }\end{array}$ \\
\hline RANK & U.S. & 11 & $1,338,900$ \\
\hline 1 & Vermont & 5 & 4,600 \\
\hline 2 & Kansas & 6 & 14,500 \\
\hline 2 & Michigan & 6 & 18,400 \\
\hline 2 & Nebraska & 6 & 10,500 \\
\hline 2 & New Hampshire & 6 & 6,400 \\
\hline 6 & Illinois & 7 & 27,800 \\
\hline 6 & lowa & 7 & 21,600 \\
\hline 6 & Tennessee & 7 & 26,400 \\
\hline 6 & Wisconsin & 7 & 22,800 \\
\hline 10 & Alabama & 8 & 24,800 \\
\hline 10 & Hawaii & 8 & 6,400 \\
\hline 10 & Maine & 8 & 12,700 \\
\hline 10 & Missouri & 8 & 25,600 \\
\hline 10 & Ohio & 8 & 42,400 \\
\hline 15 & New York & 9 & 35,000 \\
\hline 15 & South Dakota & 9 & 10,200 \\
\hline 17 & Kentucky & 10 & 53,600 \\
\hline 17 & Minnesota & 10 & 29,900 \\
\hline 17 & Washington & 10 & 19,800 \\
\hline 17 & West Virginia & 10 & 17,700 \\
\hline 21 & Arkansas & 11 & 31,200 \\
\hline 21 & South Carolina & 11 & 36,500 \\
\hline 21 & Utah & 11 & 7,300 \\
\hline 21 & Wyoming & 11 & 9,300 \\
\hline 25 & Alaska & 12 & 10,400 \\
\hline 25 & Indiana & 12 & 61,600 \\
\hline 25 & Louisiana & 12 & 15,500 \\
\hline 25 & North Dakota & 12 & 9,800 \\
\hline 29 & Georgia & 13 & 62,200 \\
\hline 29 & Oregon & 13 & 25,900 \\
\hline 29 & Pennsylvania & 13 & 64,400 \\
\hline 29 & Virginia & 13 & 34,300 \\
\hline 33 & California & 14 & 17,500 \\
\hline 33 & Delaware & 14 & 4,600 \\
\hline 33 & Florida & 14 & 24,800 \\
\hline 33 & Idaho & 14 & 25,300 \\
\hline 33 & Mississippi & 14 & 61,600 \\
\hline 38 & North Carolina & 15 & 90,800 \\
\hline 39 & Nevada & 16 & 7,300 \\
\hline 39 & Oklahoma & 16 & 46,900 \\
\hline 41 & Arizona & 17 & 33,800 \\
\hline 41 & Montana & 17 & 25,800 \\
\hline 43 & New Mexico & 18 & 35,600 \\
\hline 43 & Texas & 18 & 141,200 \\
\hline 45 & Colorado & 19 & 16,200 \\
\hline
\end{tabular}

New Jersey and Rhode Island were not included in this table because they have no nonmetro counties, and data for Connecticut, Maryland, and Massachusetts were not included because these states had less than 100 nonmetro children interviewed over the 2004-2006 period.

${ }^{*}$ Average of 2004, 2005 and 2006 CPS
Table 5. 50 Counties with Highest Percent of Children Uninsured: 2000

\begin{tabular}{|c|c|c|c|c|c|c|}
\hline Rank & State & County name & $\begin{array}{l}\text { Number } \\
\text { insured }\end{array}$ & $\begin{array}{l}\text { Number } \\
\text { uninsured }\end{array}$ & $\begin{array}{l}\text { Percent of } \\
\text { children } \\
\text { uninsured }\end{array}$ & $\begin{array}{l}\text { Metro } \\
\text { Status }\end{array}$ \\
\hline 1 & TX & Hudspeth County & 686 & 450 & 39.6 & Non-Metro \\
\hline 2 & TX & Starr County & 12,583 & 8,042 & 39.0 & Non-Metro \\
\hline 3 & TX & Zavala County & 2,409 & 1,479 & 38.0 & Non-Metro \\
\hline 4 & TX & Maverick County & 11,017 & 6,613 & 37.5 & Non-Metro \\
\hline 5 & TX & Hidalgo County & 138,502 & 72,294 & 34.3 & Metro \\
\hline 6 & TX & Willacy County & 4,126 & 2,104 & 33.8 & Non-Metro \\
\hline 7 & TX & Presidio County & 1,631 & 807 & 33.1 & Non-Metro \\
\hline 8 & TX & Edwards County & 404 & 199 & 33.0 & Non-Metro \\
\hline 9 & TX & Webb County & 49,512 & 24,311 & 32.9 & Metro \\
\hline 10 & TX & Dimmit County & 2,247 & 1,076 & 32.4 & Non-Metro \\
\hline 11 & TX & Cameron County & 79,215 & 37,829 & 32.3 & Metro \\
\hline 12 & TX & Brooks County & $1,648^{\prime \prime}$ & 780 & 32.1 & Non-Metro \\
\hline 13 & $\mathrm{NE}$ & Keya Paha County & 157 & 74 & 31.8 & Non-Metro \\
\hline 14 & TX & Kenedy County & 77 & 36 & 31.6 & Non-Metro \\
\hline 15 & NM & McKinley County & 19,179 & 8,685 & 31.2 & Non-Metro \\
\hline 16 & $\mathrm{NE}$ & Arthur County & 69 & 31 & 31.1 & Non-Metro \\
\hline 17 & NM & Luna County & 5,075 & 2,285 & 31.0 & Non-Metro \\
\hline 18 & OR & Wheeler County & 223 & 100 & 31.0 & Non-Metro \\
\hline 19 & TX & Culberson County & 627 & 282 & 31.0 & Non-Metro \\
\hline 20 & TX & Zapata County & 2,876 & 1,267 & 30.6 & Non-Metro \\
\hline 21 & TX & La Salle County & 1,180 & 514 & 30.3 & Non-Metro \\
\hline 22 & $\mathrm{NE}$ & Blaine County & 96 & 42 & 30.3 & Non-Metro \\
\hline 23 & $\mathrm{TX}$ & Frio County & 3,281 & 1,418 & 30.2 & Non-Metro \\
\hline 24 & MT & Petroleum County & 86 & 37 & 30.2 & Non-Metro \\
\hline 25 & AK & Wade Hampton Census Area & 2,264 & 974 & 30.1 & Non-Metro \\
\hline 26 & TX & Hall County & 720 & 308 & 30.0 & Non-Metro \\
\hline 27 & TX & Gaines County & 3,534 & 1,505 & 29.9 & Non-Metro \\
\hline 28 & TX & Uvalde County & 5,785 & 2,428 & 29.6 & Non-Metro \\
\hline 29 & TX & Real County & 499 & 208 & 29.4 & Non-Metro \\
\hline 30 & $\mathrm{NE}$ & Loup County & 135 & 56 & 29.4 & Non-Metro \\
\hline 31 & TX & Reeves County & 2,639 & 1,094 & 29.3 & Non-Metro \\
\hline 32 & $\mathrm{NE}$ & Banner County & 160 & 64 & 28.6 & Non-Metro \\
\hline 33 & TX & Cochran County & 775 & 311 & 28.6 & Non-Metro \\
\hline 34 & TX & El Paso County & 158,671 & 63,279 & 28.5 & Metro \\
\hline 35 & LA & East Carroll Parish & 2,028 & 808 & 28.5 & Non-Metro \\
\hline 36 & SD & Todd County & "2,706" & 1,073 & 28.4 & Non-Metro \\
\hline 37 & TX & Briscoe County & 347 & 137 & 28.3 & Non-Metro \\
\hline 38 & TX & Castro County & 1,934 & 757 & 28.1 & Non-Metro \\
\hline 39 & $C A$ & Imperial County & 32,442 & 12,516 & 27.8 & Metro \\
\hline 40 & TX & Val Verde County & 10,546 & 4,051 & 27.7 & Non-Metro \\
\hline 41 & TX & Menard County & 401 & 152 & 27.5 & Non-Metro \\
\hline 42 & TX & Bailey County & 1,472 & 550 & 27.2 & Non-Metro \\
\hline 43 & $\mathrm{NE}$ & Wheeler County & 181 & 67 & 27.2 & Non-Metro \\
\hline 44 & SD & Corson County & 1,101 & 405 & 26.9 & Non-Metro \\
\hline 45 & MS & Humphreys County & 2,621 & 954 & 26.7 & Non-Metro \\
\hline 46 & TX & Terrell County & 194 & 71 & 26.6 & Non-Metro \\
\hline 47 & TX & Crosby County & "1,578" & 568 & 26.5 & Metro \\
\hline 48 & TX & Dawson County & "2,786" & $" 1,005 "$ & 26.5 & Non-Metro \\
\hline 49 & TX & Glasscock County & 319 & 114 & 26.4 & Non-Metro \\
\hline 50 & LA & Tensas Parish & "1,288" & 461 & 26.3 & Non-Metro \\
\hline
\end{tabular}

Source: U.S. Census Bureau, available at http://www.census.gov/hhes/www/sahie/index.html 
general. In both rural and urban America, children living in single-parent families are about 50 percent more likely to lack health insurance than those living in married-couple families. Racial and ethnic minorities, particularly Hispanics, are more likely than non-Hispanic whites to lack health insurance. In rural America, uninsured rates among black children are 50 percent higher than non-Hispanic white children (14 percent and 9 percent, respectively). The share of Hispanic children who lack insurance (23 percent) is more than twice that of non-Hispanic whites. Children living in rental housing are about 50 percent more likely to lack health insurance.

\section{Conclusion and Recommendations}

\section{More Children Need Coverage Than Current Levels of SCHIP Funding Enable}

Unlike Medicaid, which is an entitlement, SCHIP is a block grant. States are given a certain amount of money each year and even if additional uninsured children come forward who need coverage, the state does not get additional money from the Federal government. In 1997, Congress appropriated $\$ 40$ billion over 10 years for SCHIP block grants and funds were distributed to states on the basis of complex formula involving the number of low-income children, the number of low-income uninsured children, and the costs of providing medical care. Although state SCHIP directors note that, "large, predominantly rural, states have significantly higher transportation costs associated with serving each child served that are not factored into the funding equation." 18

Not surprisingly, it took time for states to establish SCHIP programs, and therefore the use of SCHIP funds in the program's early years were low. While states were allowed to carry over unused funds from year to year, as the SCHIP programs have developed and jobs for low-income workers deteriorated, the number of children seeking SCHIP has grown steadily since 2000. In 2007, states expect to spend $\$ 6.3$ billion on SCHIP but will only have $\$ 5$ billion available from the Federal Government. ${ }^{19}$ As this brief is being written, Congress is grappling with how to provide short-term funds to states so they won't have to restrict enrollment, or worse yet, terminate children from SCHIP.

Funding of the SCHIP program will probably be the most critical issue discussed in the reauthorization process. Hopefully, discussion will note that the number of children covered by employer-provided, private-sector health insurance (or through a union or direct purchase) declined by 2.1 million between 2000 and 2005. This underlying dynamic makes public-sector support all the more important, espe- cially in rural America where many of the economic changes have been most jarring.

To put expenditures on Medicaid and SCHIP in perspective, in 2003, the cost of providing children with Medicaid and SCHIP was about $\$ 48$ billion compared to $\$ 374$ billion for Medicare and about $\$ 66$ billion for the portion of Medicaid that supports the elderly. ${ }^{20}$

\section{Budget Decisions Should Consider Impact of Inflation}

When money was appropriated for the SCHIP programs in 1997, there was no adjustment made for the impact of inflation. Medical and health-related costs increased rapidly during the past 10 years, eroding the real value of the SCHIP dollars. Overall, a dollar in 1997 is worth only 80 cents today and the cost of medical care has increased more rapidly than most other sectors. Therefore, funds that would cover five children in 1997 will cover only four today. If annual funding rates continue unadjusted for inflation, and at the same level of the past 10 years, the number of children covered under SCHIP will fall by 43 percent. ${ }^{21}$ Clearly, just to maintain coverage at the current level will require additional funds in the SCHIP program over the next 10 years. However, even if future SCHIP appropriations were to stay at the 2007 yearly level but adjusted for inflation, more than 8 million children would remain uninsured.

\section{Investing in the Future of Rural America}

Providing health insurance to children is an investment in the future, and although every American has a significant stake in the outcome of the SCHIP reauthorization, rural America has a special interest. Public-sector insurance for children has become particularly important for a growing share of struggling families in rural America. Given the trend that fewer rural jobs provide health insurance, it is easy to forecast increased reliance on public insurance for rural children in low-income families.

The congressional funding decisions regarding the reauthorization of SCHIP will be made in the context of strong public support for providing health insurance for low-income children. A passage in a recent front-page story in The New York Times succinctly captured the mood of the public regarding health care. ${ }^{22}$ Based on recent survey data, the paper said, "A majority of Americans say the federal government should guarantee health insurance to every American, especially children, and are willing to pay higher taxes to do it...." This is consistent with several other polls which find strong public support for government health care, especially for children. ${ }^{23}$ The New York Times poll found that 84 percent of respondents supported expanding current programs to 


\section{The Impact of Health Insurance for Children}

Early investments in preventive health care pay life-long dividends. Early childhood health is clearly associated with several important dimensions of later socioeconomic status. ${ }^{25}$ Although having insurance is only the first step in improving the health of children, health insurance coverage is important. For example, studies ${ }^{26}$ show that:

- 31 percent of children without health insurance did not see a doctor in the previous year compared with 10 percent with health insurance.

54 percent of uninsured children had no well-child visit in the previous year compared with 26 percent of children with health insurance.

25 percent of uninsured children have no usual place of care compared to 2 percent of children with private sector insurance.

- 21 percent of children without health insurance have unmet dental needs compared to 4 percent of children with private health insurance.

Children who have health insurance are more likely to get a healthy start in life than those who do not have health insurance. ${ }^{27}$ A recent report from the Rand Corporation found that children enrolled in SCHIP had improved physical, social, emotional, and school-related health outcomes compared with those low-income children not enrolled. ${ }^{28}$

cover all uninsured children and most were willing higher taxes to accomplish that.

In fact, public pressure has already led several states to expand programs to provide health care coverage for needy children. Several state-level reforms in 2006 included new mechanisms to subsidize coverage for low-income families, new variations on employer or personal responsibility for insurance coverage, and new supports to help small businesses provide health insurance for their employees. ${ }^{24}$

While the FY 2008 budget submitted by President Bush would increase funding for SCHIP from the current $\$ 4$ billion a year to nearly $\$ 5$ billion dollars per year, advocates want to see an additional $\$ 60$ billion over the next five years to continue covering all the children on the program now and expand the program to cover the 5 to 7 million children who are eligible for SCHIP, but not currently enrolled. Congress is planning a budget that would allocate an additional $\$ 50$ billion to the SCHIP program over the next five years. This budget would cover all currently enrolled kids and would expand coverage to some of the 8 million children who are currently uninsured. The budget proposed by the President would result in loss of coverage for millions of children because it doesn't account for recent increased enrollment in the program and for future cost increases due to inflation.

The rapid increase and high rate of public-sector health insurance for children underscores how important the Medicaid and SCHIP programs are for rural Americans. For low-income working families, these health insurance programs are vitally important as parents try to fulfill their employment and family responsibilities. Moreover, it is difficult to think of a more effective investment in our country's future than taking steps to make sure all of our children grow up healthy.

\section{Data Used in this Report}

This analysis relies heavily on data from the Census Bureau's Current Population Survey (CPS). This is a widely used source of data on child health insurance (used by Congress to distribute federal funds for the SCHIP program), and it is one of the few sources of data on health insurance that allows analysts to look separately at rural and urban areas, and the only source that allows one to look at rural areas state by state. The March CPS, used here, asks about health insurance coverage in the previous calendar year. While the Census Bureau acknowledges that the CPS under-reports insurance coverage and other surveys, such as the National Health Interview Survey, show slightly lower rates of children without health (the NHIS shows 7.7 million children without health insurance compared to 8.3 million in CPS), the patterns of health care coverage over time and among groups from other data sources are virtually the same as those shown in the CPS.

When the Census Bureau collects data on insurance coverage, it asks respondents about eight specific types of insurance, listed below, for the previous year. For analysis based on the CPS, it is best to combine Medicaid and SCHIP into a single category because respondents are often uncertain which of these two programs provides the insurance for their children, particularly in those states where the SCHIP is part of the Medicaid program. A relatively small number of children are covered by other federal programs such as Medicare, Indian Health Service and the military.

A small number (500,000 out of 73 million) of children are not included in this analysis because the respondent's metropolitan status is not provided by the Census Bureau in order to protect the confidentiality of the respondent.

In March 2007, the Census Bureau announced that they had discovered a minor problem in the processing system for health insurance data from the CPS and released some corrected information. The corrections were relatively minor and had no significant impact on the uncorrected data presented here. 


\section{Types of Health Care Insurance Covered in the CPS}

1. Health insurance through employer or union

2. Health insurance purchased directly from an insurance company

3. Medicare

4. Medicaid including state named plans

5. SCHIP plans

6. Military health care, including TRICARE, CHAMPUS, CHAMPVA, VA

7. Indian Health Service

8. Any other health care insurance

\section{Endnotes}

1. The Kaiser Commission on Medicaid and the Uninsured, 2006, "Health Coverage for Low-Income Populations: A Comparison of Medicaid and SCHIP," The Henry J. Kaiser Family Foundation, April, publication \#7488 available at www.kff.org.

2. Presentation by Cindy Mann, Center for Children and Families, at Grant-Makers Income Security Taskforce (GIST) meeting, Georgetown University, Washington, DC, November 29, 2006.

3. Kaiser Commission on Medicaid and the Uninsured and Urban Institute analysis of HCFA-2082, MSIS and SEDS data, 2007, from presentation made by David Rousseau at KIDS COUNT conference in Nashville, Tennessee, Feb 22, 2007.

4. The term "rural" here refers to persons living outside the officially designated metropolitan areas, as classified by the U.S. Office of Management and Budget (OMB). "Urban" refers to persons living within metropolitan areas. For more information on official definitions, see OMB Bulletin No. 60-01 (December $5,2005)$, available at http://www.whitehouse.gov/omb/bulletins/ fy2006/b06-01_rev_2.pdf.

5. Other data sources such as the National Health Interview Survey show slightly higher rates of health insurance for children in low-income families in 2005.

6. These figures come from author's analysis of the March 2006 CPS.

7. SCHIP Legislation defines low-income children as those living in families with income below 200 percent of the federal poverty level, although many states have created higher ceilings.

8. It is important to recognize that nonmetropolitan counties, as officially defined by the Office of Management and Budget, changed over the 10-year period.

9. Glasmeier, Amy and Pricilla Salant, 2006, "Low Skill Workers in Rural America Face Permanent Job Loss," Policy Brief No. 2, (Spring), Carsey Institute, University of New Hampshire.

10. United States Department of Agriculture at http://www.ers. usda.gov/Briefing/Industry/.
11. O’Hare, William P., 2007, “Rural Workers Would Benefit More Than Urban Workers from an Increase in the Federal Minimum Wage," Carsey Institute, Fact Sheet No.4, Winter.

12. Some of the change between 2004 and 2005 may be due to sampling error and some may be due to changes in what counties were identified as rural or nonmetropolitan in the CPS sampling frame. Despite these caveats, the big decline between 2004 and 2005 in the share of rural low-income children without SCHIP or Medicaid coverage is disquieting.

13. DeNavas-Walt, Carmen, Bernadette D. Proctor, and Cheryl Hill Lee, 2006, "Income, Poverty, and Health Insurance Coverage in the United States: 2005." Current Population Reports, Series P60-231. Washington, DC: U.S. Census Bureau, p. 22.

14. Families USA, 2004, "One in Three: Non-Elderly Americans Without Health Insurance, 2002-2003," Washington, DC: Families USA, p. 7.

15. Alliance for Health Reform, 2006, Chapter 1: The Uninsured, at www.allheath.org cited in Families USA, Health Action 2007 Tool Kit.

16. Annie E. Casey Foundation, 2006, 2006 KIDS COUNT Data Book. Baltimore, MD: Annie E. Casey Foundation.

17. These are model-based estimates from the Census Bureau. While estimates for any individual county may be suspect, I think using this data to show patterns among types of counties is a valid use of the data. Data for all counties are available from the Census Bureau at http://www.census.gov/hhes/www/sahie/index.html.

18. See Bergman, David, 2005, "Perspectives on Reauthorization: SCHIP Directors Weigh In." Portland, ME: National Academy for State Health Policy, pp. 7 and 15.

19. Peterson, Chris, 2006, SCHIP Original Allotments: Funding Formula Issues and Options, Washington, DC: Congressional Research Service.

20. Families USA, 2007, National Grassroots Meeting Health Action 2007 Tool Kit, Washington DC: Families USA.

21. Kaiser Commission on Medicaid and the Uninsured, 2007, The President's FY 2007 Budget Proposal: Overview and Briefing Charts, available online at http://www.kff.org/uninsured/ upload/7472.pdf

22. Toner, Robin and Janet Elder, 2007, "Most Support U.S. Guarantee of Health Plans," The New York Times, March 2, 2007, page A1.

23. Kaiser Family Foundation, 2006, "New Poll Finds Broad Support Among Democrats, Independents, and Republicans for Drug Price Negotiation, Reimportation, and Prioritizing Children for Coverage of the Uninsured," Press Release, Washington, DC, December 8; and Every Child Matters Education Fund, "2005 National Child Health Poll," Washington, DC. Available online at http://www.everychildmatters.org/. 
24. Burton, A., I. Friedenzohn, and E. Martinez-Vidal, 2007, "State Strategies to Expand Health Insurance Coverage: Trends and Lessons for Policymakers," New York, NY: The Commonwealth Fund.

25. Palloni, Albert, 2006, "Reproducing Inequalities: Luck, Wallets and the Enduring Effects of Childhood Health." Demography 43 (4), 587-615.

26. Campaign for Children's Health, 2006, No Shelter from the Storm: America’s Uninsured Children. Washington, DC: Families USA, Table 7, p. 8.

27. For more comparisons of health care differences between children who have health insurance and those who do not, see National Center for Health Statistics, CDC, 2006, Summary of Health Statistics for U.S. Children: National Health Interview Survey 2004.

28. RAND, October 2006, "Filling the Health Care Gap for Children: How is SCHIP Faring?”, Child Policy Research Newsletter, p. 2.

\section{A U T H O R}

William P. O'Hare is a Rural Fellow with the Carsey Institute and a Senior Fellow with the KIDS COUNT project at the Annie E. Casey Foundation.

\section{A C K N O W L E D G E M E N T S}

The author thanks Jocelyn Guyer at Georgetown University, John Seavey at the University of New Hampshire, Allison Orris of the Center on Budget and Policy Priorities, and Jenny Sullivan of Families USA for their thorough review of this brief, and is grateful for the assistance of the staff at the Carsey Institute, including Mil Duncan, Amy Seif, and Sarah Savage. The author also thanks David Rousseau from the Kaiser Commission on Medicaid and the Uninsured

\section{A UNIVERSITY NEW HAMPSHIRE}

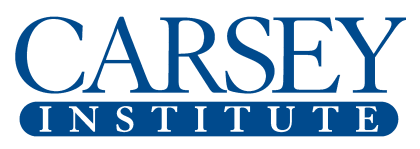

Building knowledge for families and communities in the 21st Century.

The Carsey Institute at the University of New Hampshire conducts independent, interdisciplinary research and communicates its findings to policymakers, practitioners and the general public.

Huddleston Hall

73 Main Street

Durham, NH 03824

(603) 862-2821

www.carseyinstitute.unh.edu

The Carsey Institute Reports on Rural America are supported by the Annie E. Casey Foundation's initiative to strengthen rural families, the Ford Foundation, and by the W.K. Kellogg Foundation. 